\title{
Ole tegner og fortaller \\ Om den semiotiske forskel på billeder og tekst
}

\author{
Ole TogebY
}

Nordisk Institut, Aarhus Universitet, Danmark

The basicnotion in semioticsis taken to be, not'sign', but'representation', which is defined as 'something that indicates something for someone that it is designed to indicate'. Paintings, oral linguistic utterances and written texts, which are examples of external representations, and perceptual representations and conceptual representations, which are examples of internal (mental) representations, all share the two criterial features of being about something and the possibility of misrepresen-tation (conditions of satisfaction). - A distinction is made between pictures, that are analog, i.e. holistic and looking like what they indicate, and texts, that are digital, i.e. consisting of discrete parts and indicating by convention. Hybrid representations have mixtures of analog and digital features, and komplex representations are compositions of analog an digital representations in one communicative application. - Peceptuel representation is analog, holistic and based on correspondence between what is in front of the eyes and what is in the mind of the beholder; conceptual representation is digital representation by which the discrete parts of what is perceived count as something by convention. - Both man and cat have both perceptional and conceptional representations of external objects. But only man can distinguish the figure (subject) from the ground in a picture, and interpret a painting of a pipe, not only as a painting, but also as a painting of a pipe. In addition to these types of mental processes, interpretation of digital texts demands knowledge of both an inventory of letters (the alphabet) and an inventory of morphems (the lexicon) because texts (both spoken and written) have double digitalisation. The main differences between texts and pictures are the following: texts are acts in time, double digitalised, based on both compositionality and functionality, anchored to the now of the communication, have logical syntax, are unambiguous propositions that can be true or false, are learnt socially, and predominantly cognitive. Pictures are objects in space, analog, based on functionality, not anchored, no logical syntax, ambiguous, not true or false, but with resemblance, biologically learnt, and visual.

\section{DEFINITIONER}

Ordet tegn er ikke velegnet som teknisk term i en videnskabelig tegnteori (semiotik eller semiologi), for i dagligsproget har ordet firfoldig polysemi: 1) 'noget skrevet eller tegnet som har en betydning, eventuelt i kombination med andre tegn', tegn for = NOTATION, 
symвоL, fx lighedstegn ; 2) 'en omstændighed som tyder på noget' tegn på = VARSEL, INDIKATION, sYMPTOM, fx et tegn på sygdom, svaghedstegn, 3) 'en bevægelse eller handling man gør for at udtrykke en bestemt hensigt eller kommando', tegn til = SIGNAL, cyklisten glemte at give tegn; 4) 'en situation som domineres af en bestemt handling eller følelse', fx weekenden står i oprydningens tegn. (NDO)

Den amerikanske filosof Charles Sanders Peirce, som ofte betragtes som grundlæggeren af semiotikken, inddeler tegnene i ikoner, indicier og symboler (Peirce 1994: 100ff., Peirce 1958: 391), men denne inddeling er ikke forenelig med den definition som foreslås her. I k o n e r, som hos Peirce er defineret ved deres lighed mellem tegnbæreren og tegnindholdet, svarer til det jeg vil kalde a na loge billeder, der er bestemt af mere eller mindre på forskellige dimensioner. På dansk bruger man imidlertid normalt ikke ordet tegn om analoge repræsentationer; om billedet på en tændstiksæske kan man næppe sige at det er tegn på eller tegn for Tordenskjold. Ikke desto mindre er det rimeligt at behandle analoge billeder i semiotikken.

Indicier, som hos Peirce defineres ved årsagsrelation mellem tegnbæreren og tegnindholdet, er ikke uden videre at betragte som tegn her. Kun de indicier som er udformet til at indikere (som har fået tillagt intentionalitet), opfatter jeg som 'tegn'. En vejrhane der viser hvad vej vinden blæser er et tegn, for den er udformet til at vise vindretningen; en røgsøjle fra en skorsten, der også viser hvad vej vinden blæser, er ikke noget tegn, for skorstenen og røgen er ikke udformet til det. Peirce's s y m boler er endelig det som her kaldes en digitale sprogtekster.

I semiotikken bør man således ikke behandle 'tegn på' (Peirce's indicier, VARSEL, INDIKATION, sYMPTOM), men både 'tegn til' (signAL) og 'tegn for' (NOTATION, sYMBOL), nemlig intentionale, både analoge billeder og digitale (mundtlige eller skriftlige) sproglige tekster. For at slippe ud af denne ordforbistring, vil jeg i det følgende udkast til en tegnteori som genstand for undersøgelsen definere, ikke begrebet 'tegn', men begrebet 'repræsentation', og semiotikken burde således kaldes en repræsentationsteori. Definitionen på en repræsentation kan lyde således (Chandler 2002: Ch. 1, Dretske 1995: 73, Togeby (2005):

En repræsentation defineres som noget der for nogen angiver noget som det er udformet til at angive.

Efter denne definition er både et billede af Tordenskjold, en replik i en samtale og et hjemmelavet vejskilt en repræsentation:

1)

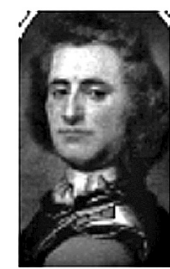

Klokken er kvart i to

1) Portræt malet 1719 af Balthasar Denner. Det hænger nu på Frederiksborgmuseet. Maleriet 
er siden 1882 reproduceret på tændstiksæskerne fra H.E.Gosh \& Co. - Skriftlig gengivelse af en mundtlig replik der er svar på spørgsmålet: Hvad er klokken? - 2) Hjemmelavet vejskilt ved Gravenshovedvej, eget foto.

Efter definitionen er repræsentationer bestemt ved intentionalitet, dvs. at de er om noget andet end sig selv, og at de har MULIGHED FOR MISvISVISNING af det de repræsenterer (Dretske 1995: 28) eller hvad der kommer ud på det samme: rigtighedsbetingelser (conditions of satisfaction, Searle 1999: 100): Rigtighedsbetingelsen for replikken er at klokken er 13:45, rigtighedsbetingelsen for billedet af Tordenskjold er at Peter Wessel faktisk så nogenlunde sådan ud, og rigtighedsbetingelsen af vejskiltet kan være at der faktisk ind imellem leger børn på dette sted, så man skal passe på.

Intentionaliteten ligger i definitionens angiver noget som den er angivet til at angive. Det er dette definerende træk der udelukker Peirces indeksikalske tegn. Repræsentationsbærere skal altså ikke blot for en bevidsthed angive noget andet end sig selv, men også gøre det for to bevidstheder og fungere som kommunikation, fællesgørelse af repræsentationsindholdet.

Man kan blandt repræsentationerne skelne mellem analoge repræsentationer, dvs. billeder - eller fx et analogur, og digitale repræsentationer, dvs. sprogtekster - eller fx et digitalur (Watzlawick/Beavin/Jackson 1968: ch. 1, Wilden 1972: ch. 7). A naloge repræsentationer, billeder, angiver som en helhed at der i den angivne sag er mere eller mindre af en eller flere egenskaber på en eller flere dimensioner. Digitale repræsentationer, sproglige ytringer og tekster, er sammensat af mindre, diskrete enheder, som hver især angiver at noget fra et begrænset udvalg af muligheder (et inventar, fx et alfabet eller en ordbog) er til stede eller ej, fx $q$ og $\sigma^{\star}$ på en toiletdør, eller $A, B \ldots N, O, P$, $R$...Ø..Å. De diskrete enheder kan så kombineres efter syntaktiske regler til enheder på et andet og højere niveau af mening, fx BØRN.

Modsætningen mellem analog og digital ser umiddelbart ud som modsætningen mellem rød og lang: digital betyder 'opdelt i diskrete dele', og modsætningen er 'holistisk' og 'kontinuerlig'; analog betyder 'som ligner', og modsætningen er 'arbitrær' og 'konventionel'. Men modsætningen står i virkeligheden mellem tekstegn som er sammensatte af konventionelle elementer og billedtegn som er helheder der ligner: En 'tekst' er en repræsentation inddelt i diskrete elementer der står i et arbitrært og konventionelt forhold til det de enkeltvis og i kombination angiver. Et 'billede' er en holistisk og kontinuerlig repræsentation der ligner det som den som en helhed angiver.

Viseren på et analogt ur har altid bevæget sig mere eller mindre på sin vej rundt på urskiven, og det angiver om der er gået mere eller mindre tid. Et digitalur angiver om klokken er 13:45 eller ej. Inventaret af mulige elementer er her 2 x 12 forskellige navngivne timer og 60 forskellige minutter.

Mange repræsentationer er hybride, dvs. blandinger af analoge og digitale repræsenteringer. De kan være digitaliserede analoge repræsentationer eller analogiserede digitale repræsentationer. Vejskilte om ubevogtet jernbaneoverskæring (billede 3) består både af noget analogt (billedet af toget) og noget digitalt (den røde trekant som angiver at det er en advarsel). 
Man må desuden skelne mellem blandingsrepræsentationer, hvor der i en og samme repræsentationsenhed er både analoge og digitale træk (billede 3), og så komplekse kommunikative henvendelser der består af kombination af tydeligt afgrænsede digitale tekster og analoge billeder. Det kan være en roman med illustrationer, en tegneserie, et ugeblad eller en reklame med tekst og billeder, et foredrag med power point (billede 4). I disse tilfælde er det den kommunikative henvendelse der er kompleks, mens de i den kommunikative henvendelse indgående delrepræsentationer kan være enten analoge billeder, digitale tekster eller blandinger (Togeby 2005).

3)

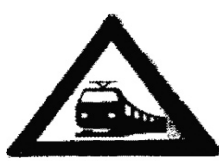

4)

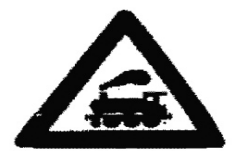

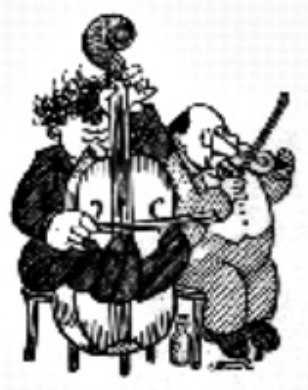

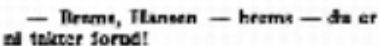

3) Advarselsskiltet om ubevogtet jernbaneoverskøring som de ser ud syd og nord for den tyskdanske grænse. - 4) 157 Nye fluer samlet og illustreret af Storm P.SV Press A/S, MCLMXXIII.

Definitionen af repræsentation indebærer at begrebet ikke blot omfatter ydre repræsentationer som billeder, ytringer og tekster, men også indre (fænomenologiske) repræsentationer, som skal omtales nærmere i det følgende. Der kan også skelnes mellem indre analoge, dvs. perceptuelle repræsentationer som er outputtet af sanserne for en organisme, og indre digitale, dvs. konceptuelle repræsentationer, som er organismens kategorisering af det perceptuelt opfattede (Dretske 1995: 19). Begge typer af indre repræsentationer kan ses som det at noget (en organisme) angiver noget (det sansede) som den er udformet til at angive, nemlig gennem evolutionen; øjne er udviklet for at organismen skal kunne se, og hjerne for at organismen kan kategorisere og forstå; levende væsner er udformet (designet) uden at der er nogen designer. Der skal ikke siges mere om dette filosofiske problem her (Togeby, udkommer). 


\section{Opfattelse}

Når 'repræsentation' defineres som 'noget der for nogen angiver noget som det er udformet til at angive', må organismens opfattelse (det at sanse og forstå) indgå i det forhold som defineres. I dette afsnit vil jeg derfor redegøre for hvorledes dyr og mennesker opfatter og har repræsentationer af genstande i deres omgivelser, af billeder de ser, og af tekster de ser eller hører.

Hvis jeg ser en pibe liggende på bordet, forårsager piben (fysisk og biologisk) at jeg får en oplevelse af en brun og svungen genstand, dvs. at jeg får en perceptuel repræsentation af den. Og den oplevelse jeg får af piben, må I andre antage ligner, er i overensstemmelse med og har korrespondance med den virkelige pibe, som oplevelsen er en repræsentation af, dvs. rigtighedsbetingelsen er opfyldt hvis mine øjne fungerer som de efter jeres mening skal (selv kan jeg ikke vide det).

Perceptuel opfattelse af en genstand indebærer at situationen som sanses, opfattes som én helhed, og at der i denne enkelte repræsentation skelnes mellem figur og grund. På billede 5. kan man enten se en hvid vase på en sort baggrund, eller to sorte profiler på en hvid baggrund; man kan ikke se begge dele på en gang, men man kan kippe mellem dem på et øjeblik. I alle tilfælde vil bevidstheden skelne mellem en figur og en grund.

Denne perceptuelle oplevelse af en brun og svungen genstand er således figuren i en repræsentation der som baggrund har bordet og stuen det står i. Denne figur kan jeg så genkende som hørende til kategorien 'en pibe', dvs. jeg har en konceptuel repræsentation, og jeg forstår at den kommer fra og er forankret til en genstand uden for mig, dvs. jeg forstår at jeg ikke drømmer (det kan I andre ikke vide noget om).

Opfattelse af en genstand indebærer at genstanden kategoriseres, dvs. genkendes som værende det samme som jeg kender, som hørende under en kategori som er kendt. Dette forudsætter at jeg har lært hvilke muligheder der er for genkendelse, dvs. en taksonomi over mulige genkendelige genstande. Det at genkende noget som 'det samme' er ensbetydende med digitalisering; svaret er ja eller nej, ikke både ... og eller mere eller mindre (Bateson 1973: 428).

5)

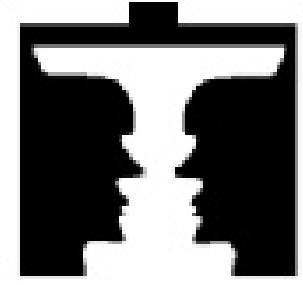

6)

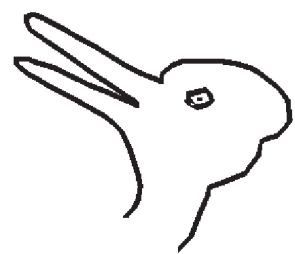

5) Rubins vase i egen tegning. - 6) Wittgensteins kaninand (Wittgenstein 1971: 249)

Dyr har også konceptuelle repræsentationer. Når en fugl nedefra flyver ind i en stor glasrude som spejler lyset, er det ikke fordi dens øjne svigter den, det er fordi den 
kategoriserer ruden som et hul i en mur, et hul som den kan flyve igennem. Dens perceptuelle repræsentation er god nok, men dens konceptuelle repræsentation er fejlagtig, og muligheden for misvisning er jo netop det definerende træk ved intentionalitet.

Når man ser en pibe liggende på bordet, sker der altså følgende: 1) perceptuel (analog) repræsentation: brune farver og svungne linjer, 2) konceptuel (digital) repræsentation: kategorisering af genstanden som en pibe og 3) erkendelse af at repræsentationen af piben i bevidstheden korresponderer med (ligner) piben på bordet (hvis sanserne virker som de skal, og man ikke drømmer).

Men hvis jeg ser et billede af en pibe:

7)

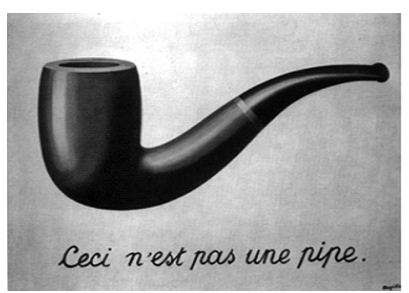

7) Magritte 1928/29: La trahison des images: Ceci n'est pas une pipe, Los Angeles County Museum of Art.

ser jeg jo hverken alene noget som kategoriseres som 'et billede', eller alene noget der kan kategoriseres som 'en pibe'; jeg ser 'et billede af en pibe'. Men ud over at kategorisere maleriet som et maleri forstår jeg at det konceptuelle indhold, 'maleri', selv har en baggrund for en figur, et motiv, der forestiller noget andet (end maleriet), nemlig: 'en pibe'.

Det konceptuelle motivindhold er ikke inde i maleriet på nogen måde som kan måles og vejes. Der er ikke nogen pibe der er del af maleriet. Oplevelsen af piben på billedet kan ikke opfattes som umiddelbart forårsaget af virkeligheden - som den indre konceptuelle repræsentation af den virkelige pibe gjorde. Beskuerne må aflede billedets intentionalitet af overbevisningen om at meningen 'en pibe' er blevet tillagt til maleriet af maleren. Billedet som ydre repræsentation er rigtigt hvis maleren har malet det godt, og billedet ligner.

Opfattelse af et billede involverer altså følgende: 1) perceptuel (analog) repræsentation af billedet, en ramme med flade og farver, 2) konceptuel (digital) repræsentation af billedet: kategorisering af det som et billede, 3) skelnen mellem baggrund og motiv i billedet, 4) konceptuel repræsentation af motivet og kategorisering af motivet som en pibe, 5) erkendelse af om billedets motiv forestiller, korresponderer med, ligner modellen.

Sådanne konceptuelle motiver er antagelig kun inde i hovedet på mennesker. Dyr - selv intelligente dyr - kan næppe indbyrdes anvende billedrepræsentationer til at dele tanker om det som billedets konceptuelle motivindhold - i anden omgang - repræsenterer. Katten ser således antagelig nok et maleri (en ramme med et farvet lærred på), men næppe en pibe. Eksperimenter viser således at katte ikke genkender sig selv i et spejl. 
I Kunsthistorien har man sat denne menneskets opdattelse af billeder på begreb; Erwin Panofsky skabte i Studies in Iconology (1939) en model med tre niveauer: 1) Værket beskrives præikonografisk (dvs. som perceptuel repræsentation), 2) motivet søges identificeret på ikonografisk niveau (dvs. konceptuelt), og 3) værket fortolkes i sin kulturelle sammenhæng på ikonologisk niveau (dvs. som kommunikativ henvendelse).

\section{Billedets Figur og GRUND, OG DETS AUTENTICITET}

I dette afsnit vil jeg kort skitsere et par blandt mange emner i ikonografien, nemlig hvorledes man skelner mellem figur og grund, og hvorledes vi opfatter motivets autenticitet. Foruden disse to er der spørgsmålene om billedets produktionsmåde, den socialt definerede billedinstitution, billedets originalitet, billedets tekniske kvalitet, motivets type, motivvalgets retfærdiggørelse og billedets realisme, men pladsen tillader ikke omtale af disse emner her.

Motivet i billedet kan træde frem (være salient) på forskellige måder: a) Billedet viser motivet som et element i én perspektivisk helhed; b) baggrunden er klippet fra og figurens grænse er billedets ramme, fx en køleskabsmagnet; c) baggrunden er neutral (ensfarvet, skraveret eller mønstret) for en eller flere (uindrammede) billeder der kan have foreskellige relative størrelser, zoom, og perspektiv, også selv om de hører til samme afbillede situation, fx figurerne på en ikon eller et kalkmaleri (billede 17); d) der er ingen figur eller grund i billedet, det er nonfigurativt. dvs. blot farvede eller mønstrede flader (billedet 8). Der kan dog godt erkendes en figur på en baggrund.

Inden for billeder hvor motivet er én perspektivisk helhed kan motivet være salient på følgende måde: a) Der er ingen figur, og derfor ikke nogen baggrund, typisk billeder af rum eller af landskaber med mange genstande; hele rummet er motivet (billede 10); b) der et tydeligvis i det perspektiviske billede en figur på en baggrund (billede 9 og 1117).

Dette kan være kommunikeret ved: i) figuren er skarp - baggrunden uskarp (billede 13); ii) figuren er én gestalt, mens baggrunden er ugestaltet, skåret af eller partiel (billede 9, 12-16); iii) figuren er i midten af billedet (billede 12, 14); iv) figuren har form som en særskilt enhed med kontur og form - baggrunden er blot en uformet masse (billede 7, 17); v) figuren opleves i perspektivet som tæt på beskueren - baggrunden længere væk (billede 12, 13, 14,15); vi) mennesker hvis ansigt kan ses, er snarere motiv end ting og personer set fra ryggen (billede 12-16). vii) motivet udpeges ved billedteksten (billede $9,18)$. Her følger en række billeder der kan illustrere forholdet mellem figur og grund: 
8)

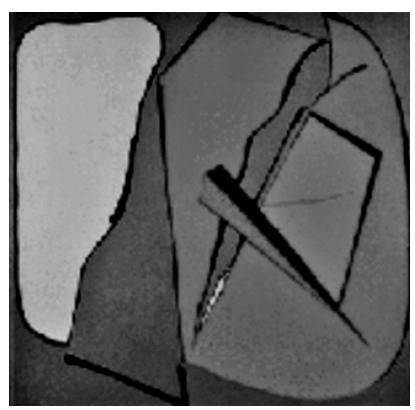

10)

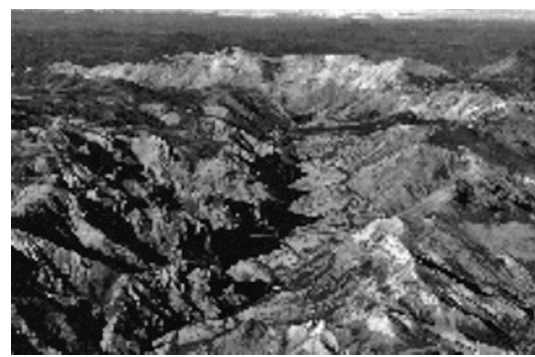

12)

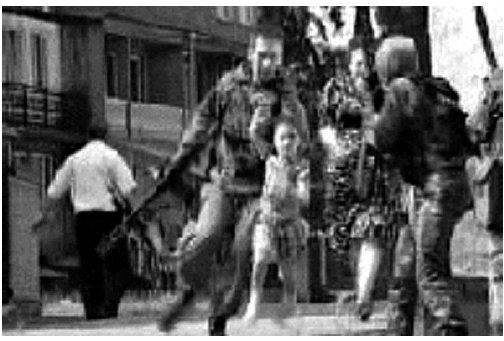

9)

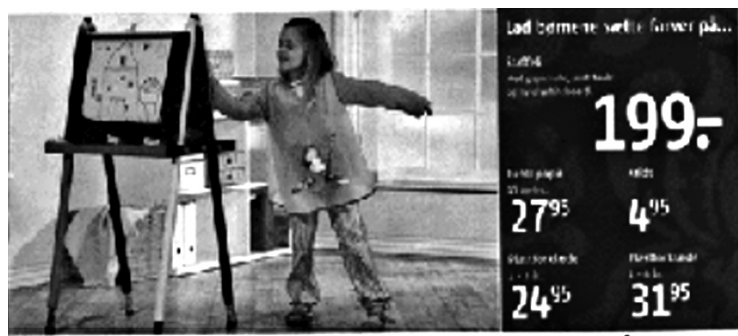

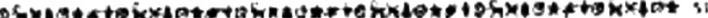

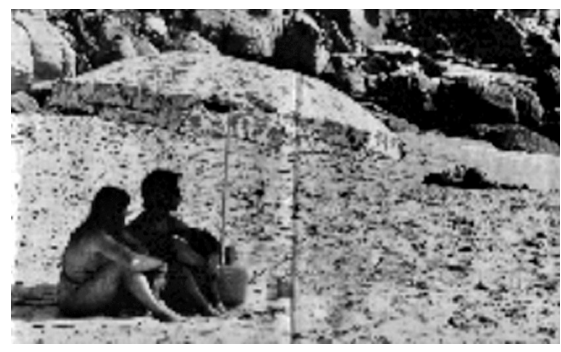

13)

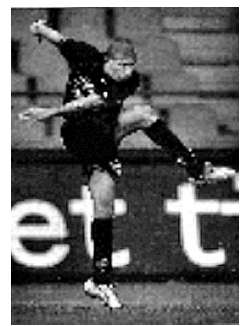

14)

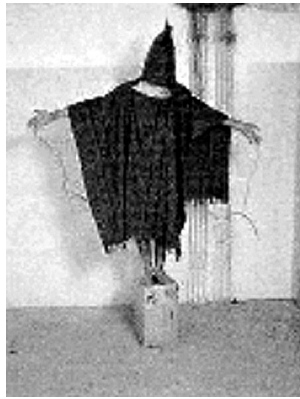

16)

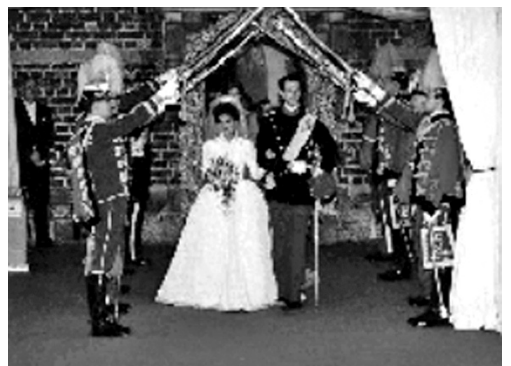


17)

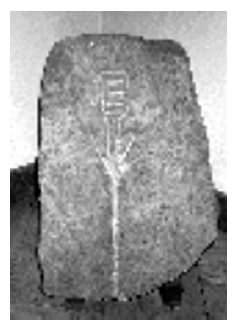

18)

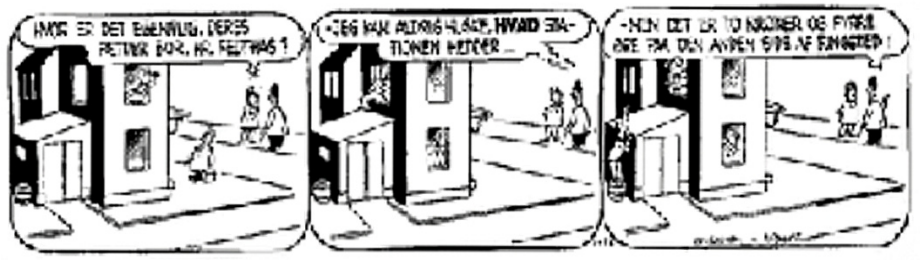

8) Richard Mortensen: Andet postume brev til Clara Jensen, 1968. - 9) Bilka-katalog Julen 2004, side 53. - 10) Postkort fra Island: Prengsli ved Landmannalaugar. - 11) Billedet er taget nær den sydspanske by Tarifa år 2000. I baggrunden ligger liget af en mand der har forsøgt illegalt at krydse Gibraltarstrædet fra Afrika til Europa. Turisterne i forgrunden forklarede at de ikke var upåvirket af strandvaskeren, men at de ikke vidste hvor de skulle henvende sig, Politiken 18. april 2004, 3. sektion side 1. - 12) En pige bliver reddet fra skolen i Beslan, Politiken 1. september 2004, side 1. - 13) Fodboldspilleren Mohammed Zidan fra FC Midtjylland, foto fra Politiken 18. sep. 2004 2. sektion side 11. - 14) Billede taget af amerikanske soldater $i$ Abu Ghraib-fængslet i Irak 2003. "Et billede viser en mand der balancerer på en kasse med elektriske ledninger bundet om håndleddene. Ifølge militæret fik han at vide, at han ville blive dræbt, hvis han faldt ned fra kassen." Politiken 30. april 2004 1. sektion side 8. - 15) En reklame for Estée Lauder i Alt for Damerne nr. 16, 15. april 2003, side 4. - 16) Joachim og Alexandras bryllup 18.11.1995. Politikens hjemmeside. - 17) Håndtegn, sten med helleristning fra Klokkerbanken, Risbjerggård, Nordsjælland fra ca. 200 før vor tidsregning. - 18) Fedthas af Engholm \& Brandt. Dansk Familieblads Billedhæfte nr. 30. Julen 1955.

De syv kriterier for hvad der er figur eller motiv i et billede, kan være i modstrid med hinanden, fx er det i billede 12 soldaten og pigen der løber mod os, der er figuren, selv om de er uskarpe, mens baggrunden er skarp; i billede 11 er det parret til højre og strandvaskeren til venstre der er figuren, mens midten af billedet er baggrunden; sad billedet 9 i en families fotoalbum, ville pigen være motivet, men det er med teksten til højre for billedet angivet at det faktisk er staffeliet der er motivet, mens pigen blot er baggrunden. På hvert af de tre billeder på billede 18 er figurerne (personerne der taler) længst væk, mens det der er nærmest beskueren, er grunden i billedet. Her sker der så oven i købet også interessante ting, men det er rene afledningsmanøvre fra tegnerens side.

Enhver beskuer af billeder må også (igen blandt mange andre ting) have en opfattelse af billedets autenticitet. Her er der følgende muligheder: a) Billedet a f bild e r et AUTENTISK motiv, dvs. motivet indgår i sin egen institution: i) Motivet er SPONTANT, dvs. et landskab (og andre ting uden bevidsthed) eller personer fremstillet således at de ikke synes at vide at de afbildes (billede 10, 12, 13, 14). ii) Motivpersoner er вEvidste om at de afbildes, men det ændrer ikke ved deres handlinger (billede 16.). iii) Motivet er OpsTILLET til afbildning, men stadig som sig selv og i sin egen institution (billede 1 og måske 11).

b) Billedet fremstiller (forestiller) et UAUTENTISK motiv, dvs. motivet indgår ikke i sin egen institution, men spiller en rolle i billedproduktionens institution, og personer antages at have viden om denne: i) Billedet er en del af en FiкTIONsfilm (og institutionen er således en anden end billedproducentens), fx stilbilleder fra film. ii) Motivet er 
ARRANGERET for at billedet kan blive produceret, personer lader som om de ikke ved at de bliver afbildet (billede 9, 11, 15). iii) Billedet er KONSTRUERET; billedproducenten er ikke og har ikke været i kontakt med motivsituationen (billede 18 og måske 17).

Billede 11 er interessant, for skønt det fremstiller motivet som om det er autentisk, kan det ikke være det. Parret kan ikke have siddet sådan efter at både myndighederne og fotografen, har fået viden om at manden i baggrunden er død; fotografen må have bedt de to strandgæster om at sætte sig hen som de sad. Spørgsmålet er også om liget har fået lov til at ligge indtil fotografiet blev taget. Og hvis det faktisk ikke er et lig, hvad er det så?

\section{Sproglige tekster}

Selv om Saxo i Danmarks historie 8. bog skriver at Starkads digt om Bråvallaslaget er overleveret fra mund til mund, og ikke i skrift, fandt man i 1833 i Runamo i Blekinge i en blød diabasklippe nogle runer som som måtte være dette digt, det lod sig imidlertid ikke tolke umiddelbart.

19)

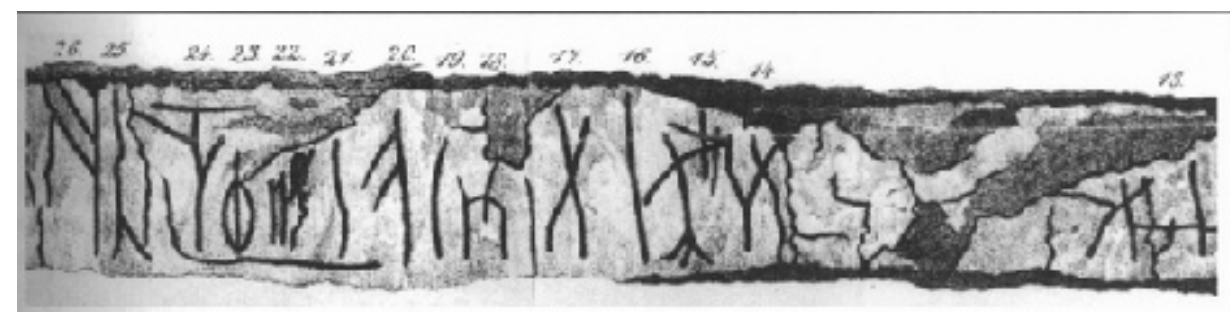

Et stykke af Runamoklippen tegnet 1833 af C.F.Christensen

Runologen Finn Magnusen hævdede dog - på baggrund af en tegning af C.F. Christensen - i en 740 siders afhandling at hvis man læste tegnene bagfra, stod der: Hildekind indtog riget/ Gard huggede/ Ole ed gav/ Odin vie runerne/ Ring få fald på muld/ Alfer, elskovsguder/ Ole hade/ Odin og Frej/ og asers slægt/ ødelægge, ødelægge/ vore fjender! Unde Harald/ en stor sejr.

20)

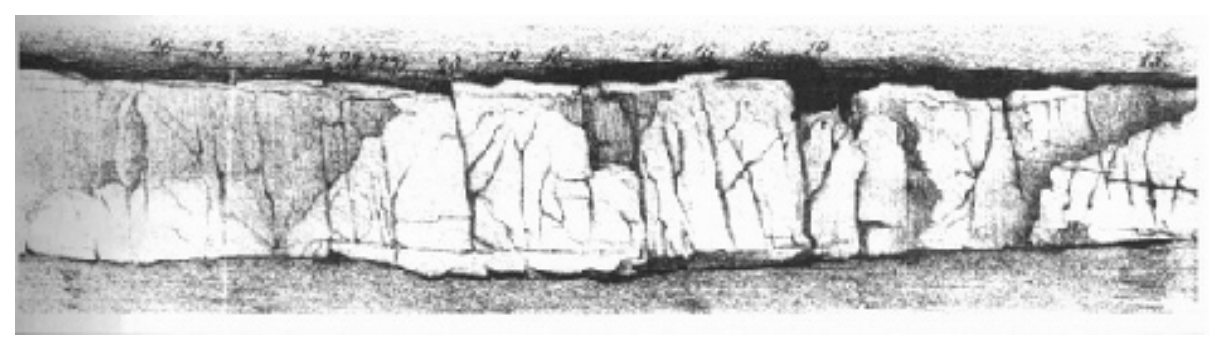

Det samme stykke af Runamoklippen tegnet 1844 af C.O. Zeuthen

I 1844 påviste J.J. Worsaae dog - på baggrund af en tegning af C.O. Zeuthen - at der blot var tale om fordybninger i klippen forårsaget af rindende vand. Og dermed forsvandt Bråvallaslaget, Hildekind, Ole og Odin som dug for oplysningens sol (Markvad 2003: 33ff.). 
Som man kan se af dette eksempel, kræver opfattelsen af digitale repræsentationer at helheden deles op i digitale elementer, som hver især kan genkendes som hørende til et inventar af elementer, som konventionelt angiver noget andet end det de eventuelt måtte ligne, nemlig et inventar af tal eller bogstaver. Der er forskel på tal og bogstaver. Tallene har enkelt digitalisering og sproget dobbelte digitalisering. Skrevne tal er digitale repræsentationer med et inventar der består af 10 taltegn $(0,1,2,3,4,5,6,7,8,9)$, og nogle aritmetiske tegn $(+,-, x, /,=)$ og de kan så kombineres efter syntaktiske regler til fx: 1395 og 4 × $37=148$, hvor helhedens mening er kompositionelt bestemt. Aritmetiske ligninger har fuld kompositionalitet.

Skrevne tekster er digitale repræsentationer med dobbelt ditalisering (dobbelt artikulation, Chandler 2002: 10). Der er her to inventarer på spil, 1) alfabetets bogstaver og 2) ordforrådets leksikon af morfemer. Et morfem udgøres af en række af bogstaver - men uden kompositionalitet og funktionalitet, og ytringer (der tæller som udsagn og sproghandlinger) er så sammensat kompositionelt og funktionelt af morfemer.

Kompositionalitet er det forhold at meningen med en enhed afhænger af summen af meningen af delene i den og meningen med måden de er kombineret på. Funktionalitet er det forhold at meningen med en enhed afhænger af meningen med den helhed som den indgår i, og af dens funktion i denne. Og helheden kan efter den hermeneutiske cirkel ikke opfattes kompositionelt før delene er opfattet, mens delene ikke kan opfattes funktionelt før helheden er forstået. Dette kan illustreres med følgende to tegninger.

21)

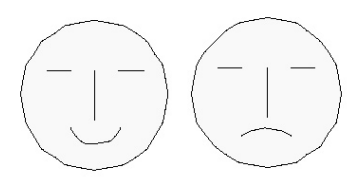

Det er givet at helheden, opfattelsen af et ansigt, er afhængig af opfattelsen af delene. Uden to øjne, en næse og en mund, omkranset af hovedets form, ville det ikke være et ansigt. Men man kan også se hvorledes tolkningen af delene er afhængig af opfattelsen af helheden: øjnene - som på begge ansigter ret beset på begge ansigter ikke er andet end to tankestreger - må på det venstre ansigt opfattes som smilende, mens øjnene på det højre ansigt er sure - selv om de er identiske.

Meningen med den digitale tekst PAS PÅ - BøRN er bestemt ved kompositionalitet: passe på betyder 'være forsigtig med' eller 'være vagtsom over for', bydeformen betyder 'at det er noget du'et skal gøre', og barn betyder 'person under 13 år'. Sætningen kan derfor bogstaveligt betyde 'vær vagtsom over for personer under 13'. Men meningen med teksten er også bestemt ved funktionalitet; når det er et vejskilt, er betydningen af pas på nok snarere 'vær forsigtig med', og børn er nok snarere en nominalsætning end et 
objekt, og betyder: 'der leger måske børn på vejen'. Begge tolkninger er kompositionelt mulige, kun den sidste funktionelt relevant.

Forholdet mellem grafemer (bogstaver) og morfemer er hverken kompositionelt eller funktionelt. Forholdet mellem morfemet og det det er en repræsentation af, er derfor arbitrært og konventionelt. Forholdet mellem morfemer og sætninger i en sproglig tekst er både bestemt ved kompositionalitet og ved funktionalitet. Men forholdet mellem den tekstlige repræsentation og det den repræsenterer, er - på grund af den dobbelte digitalisering - også altid arbitrært og konventionelt.

I et billede er der ingen diskrete dele, men kun en helhed af linjer, former og farver. Et billede har til gengæld 'indzoombarhed', dvs. man kan zoome ind på et mindre område af billedet og stadig have et billede, eventuelt af et andet motiv; i billede 9 kan man således zoome ind på pigens hoved og have et billede af en pige, eller på staffeliet og stadig have en billede, nu af et staffeli. I tekster kan man ikke zoome ind og stadig have en tekst (der skulle have indhold der er en del af det oprindelige indhold); zoomer man ind på øRN, får man ikke en sætning.

I tekster er forholdet mellem helhed og del både kompositionelt og funktionelt. I billeder er forholdet mellem helhed og del helt overvejende funktionelt, eftersom der ikke er nogen diskrete dele: Hvad motivet på et billede kategoriseres som, afhænger således dels af billedets egenskaber (linjer, former, farver), men også altid af den sociale kanal, billedets art, og tærskelteksterne.

Disse eksempler viser tydeligt at opfattelsen af en digital tekst indebærer flere processer end opfattelsen af et billede. Opfattelse af skiltet med teksten PAS PÅ - BØRN må nødvendigvis involvere følgende dele: 1) perceptuel (analog) repræsentation af skiltets kanter, flade og farver; 2) konceptuel (digital) repræsentation af det med kategorisering af det som et skilt; 3) skelnen mellem baggrund og motiv (bogstaverne); 4) konceptuel (digital) repræsentation af motivet som bogstaver; 5) erkendelse af at bogstaverne tæller som grafemerne: a ø å b n p r s; 6) genkendelse af rækker af grafemer som morfemerne pas på børn. 7) erkendelse af at morfemer tæller som betegnelser for begreber; 8) erkendelse af at kombinationen af morfemer tæller som en sætning med udsagns- og sproghandlingsindhold: 'Pas på når du kører; der kan være børn på vejen som du ikke må køre over'.

Digitale tekster kan siges at have fire typer af indhold som udtrykket angiver for modtagerne: interaktionel mening som konstituerer sociale relationer, og som har sociale konsekvenser for dem der interagerer, informationel mening som har grader af relevans for modtagerne, propositionel mening som har realitetsstatus i forhold til den omtalte situation, og konceptuel mening som har genkendelighed i forhold til den omtalte verden (Togeby 2003: 8). 
22)

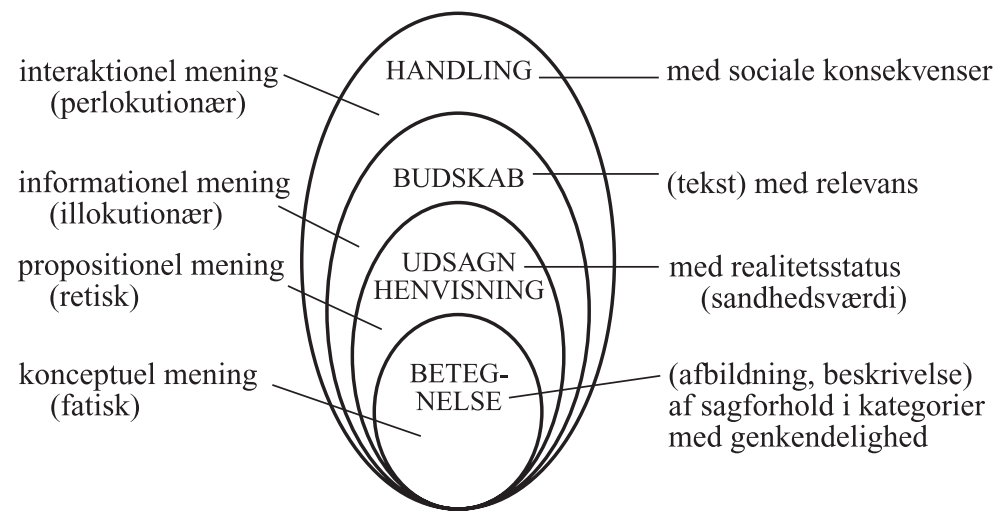

Billedrepræsentationer har ikke propositionelt indhold eller informationel mening, ingen realitetsstatus og ingen relevans. Billeder fremkalder således som repræsentationsindhold kun konceptuel mening. Spørgsmålet er om en analog repræsentation kan fungere så den tæller som en handling med bestemte sociale konsekvenser; den er lavet (malet, fotograferet, indhugget i sten) i en situation med en bestemt hensigt, og den har givetvis psykologisk effekt eller virkning på beskueren. Men sociale konsekvenser kræver vel en digitalisering der gør det muligt om handlingen 'tæller som' det ene med den ene sociale konsekvens, eller det andet med den anden sociale konsekvens - og dette er netop digitalisering. Så konklusionen må være et billede forestiller noget (motivet) , og det er lavet (stillet frem) i en situation med en bestemt hensigt så det har psykologisk virkning på beskuerne. Punktum.

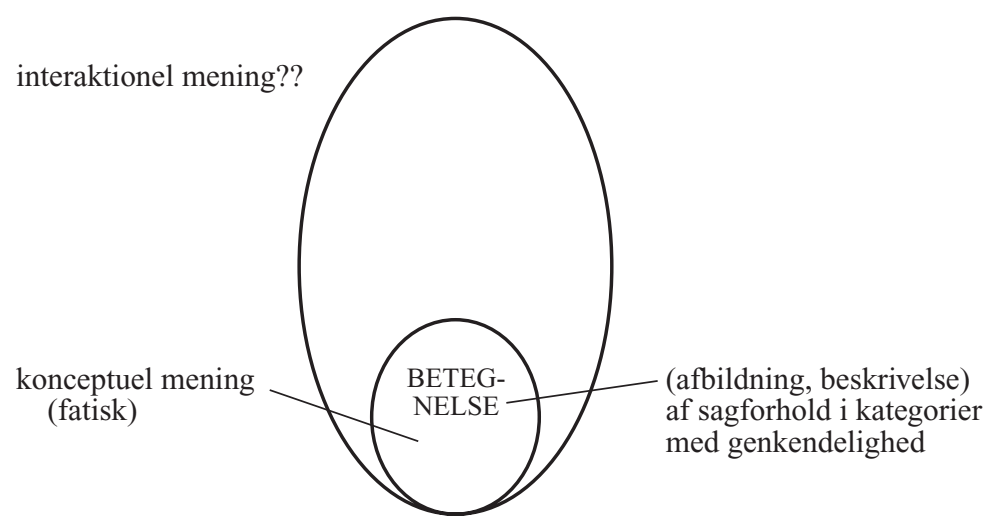




\section{FoRSKELLE PÅ TEKST OG BILLEDE}

De træk som er beskrevet og diskuteret i det foregående, kan sammenfattes i følgende skema over forskellene på digitale tekster og analoge billeder:

\section{TEKST}

Handling i tid der kan gentages, som både forudsætter og konstituerer sociale relationer (både tale og skrift), og som har perlokutionære konsekvenser.

Digital, dvs opdelt i diskrete gentagelige dele som kombineres til uindzoomelige enheder med enten-eller-betydning

Dobbelt digitalisering med to inventarer med genkendelige elementer: et alfabet af bogstaver og et leksikon af morfemer. Morfemer udgøres af fikserede rækker af fonemer.

Både kompositionalitet og funktionalitet: Meningen med en enhed er både bestemt af meningen med delene og måden de er kombineret på, og af meningen med den helhed de indgår i, og enhedens funktion heri.

Involverer deiktiske udtryk for ankrede i kommunikationssituationens tid, rum og sociale rum. Med dem kan man henvise (referere) til individer i omverdenen.

Har logisk syntaks med negation, hvis ... så, enten ... eller og sandhedskonstans: hvis $X$ så $Y,=$ ingen $X$ uden $Y ; X \rightarrow Y=\sim(X \& \sim Y)$.

Udsag n der består af henvisning (reference) til genstande og omsagn om dem i tid.

Entydig i enten-eller-angivelsen af et element i inventaret.

Rigtighedsbetingelsen kan være sandhed i forhold til den virkelighed udsagnet er et udsagn om.

Har socialt indlært fælles mening som delvist er konstrueret og overvejende intellektuel.

Overvejende kognitiv da den er tværperceptuelt oversættelig mellem det visuelle og det auditive.
BILLEDE

Genstand i rum der er produkt af en handling, som kan kopieres, men ikke gentages, som har psykologiske effekter, men som forudsætter sociale relationer.

Analogt, dvs. kontinuerlig uinddelt indzoomelig helhed med både-og- og mereeller-mindre-betydning.

Ingen digitalisering, der er intet inventar med genkendelige elementer.

Især funktionalitet: Meningen med en enhed er bestemt af dens egenskaber og af meningen med den helhed den indgår i, og af dens funktion heri.

Ingen deiksis, derfor u for a n k ret i tid, rum og socialt rum, kan ikke henvise, men kun afbilde generiske genstande.

Ingen logiske konneksioner - kan derfor ikke udtrykke negation, hypotese, tid, eller identitet, lighed eller forskel.

Kommmunikativ henvendelse med kategorisering og angivelse af egenskaber og kvaliteter.

Fle r ty dig ibåde kategorisering og beskrivelse af egenskaber.

Rigtighedsbetingelsen drejer sig om mere eller mindre lighed med det det forestiller eller gengiver.

Har biologisk individuelt indlært mening som er opdaget og erfaret og overvejende emotionel.

Overvejende perceptuel da det kun er visuelt. 
Komplekse kommunikationsenheder der består af både tekster og billeder der handler om det samme, kan som hovedsagen enten have teksten (billedbøger, avisartikler, reklamer), billedet (maleriudstilling, fotoalbum), eller den komplekse sammenkobling af tekst og billeder (tegneserier).

Hvis billedet er hovedsagen må billedteksten opfattes som en tærskeltekst, som tekster også kan have, dvs. en tekst der angiver billedets titel, maler, produktionsår. I så fald kan teksten FORANKRE billedet deiktisk og historisk, nemlig ved a) BiLledForAnKring: Teksten forankrer billedudtrykket (billedet som genstand), dvs. angiver tid, sted, producent og produktionsmåde, fx billede 24.: Anna Ancher 1883 86. b) Motivforankring: Teksten forankrer billedindholdet, det billedet gengiver, billede 25.: Kennedy forlader kapitol efter sin indsaettelse som USAs proesident 20.1.1961. Dette kan kun ske hvis produktionsmåden (fx fotografi) angiver at der er et årsagsforhold mellem begivenheden og billedet.

24)

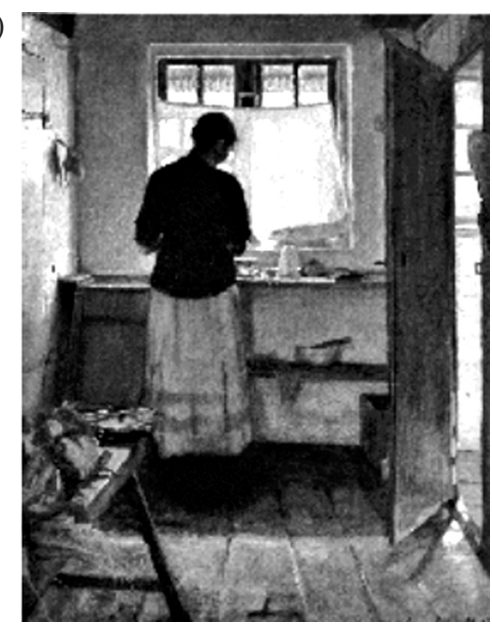

25)

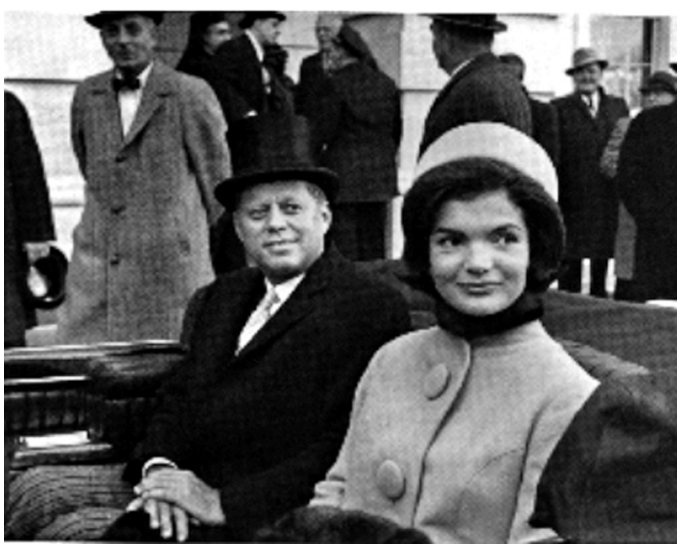

24) Anna Ancher: Pigen i køkkenet, 1883, 86, Den Hirschsprungske Samling. - 25) Kennedy forlader Capitol 20.1.1961, i Den Store Danske Encyklopædi, under opslaget "Kennedy".

Teksten kan angive hvad der er motivet (fokus) i billedet og KATEGORISERE det (dvs. angive hvad figuren forestiller), fx billede 24 Pigen $i$ køkkenet, eller teksten kan FORLÆNGE billedet $\mathrm{i}$ tid, rum eller mentalt rum; det kan ske ved a) Teksten angiver hvad personen på billedet siger og eventuelt hvilke andre lyde der er ( billede 4, 18); b) Teksten angiver hvad der skete før, eller hvad der sker siden den frosne situation som billedet fremstiller fx billede 14; c) Teksten fortæller hvad der ville kunne ses uden for billedets ramme billede 12; d) Teksten fortæller ikke-synlige egenskaber ved det billedet forestiller, fx prisen på varen i et katalog, fx billede 9 .

Tekster kan være DEL AF мотIVET, fx et skilt med bogstaver som noget af det billedet forestiller, fx billede 7 .

I komplekse repræsentationer hvor teksten er hovedsagen, kan billedets funktion i forhold til den kommunikative henvendelses emne være a) at billedet GENGIVER noget 
som er benævnt i teksten. Billede og tekst er to repræsentationer af samme sag. Til en artikel i encyklopædien om Kennedy vises billede 25. Gengivelser er som regel, som her, forankerede til kommunikationssituationen med en billedtekst. b) Billedet FremstilLER (forestiller) en kategori eller en type som omtales i teksten (dvs. billedet viser hvordan et emne eller en situation fra teksten kan s e ud, ikke hvordan den så ud). Billedet kan være i) lavet som en ILLUSTRATion til teksten og forankres eventuelt til tekstens generiske eller fiktive personer, genstande og begivenheder, billede 4, 18. Som illustrationer finder man også fremstilling af en art i en fuglebog med malede (eller fotograferede) billeder af de fugle som omtales i teksten. ii) Billedet UDFOLDER noget som kan have en underforstået METAFORISK lighed med noget som teksten handler om, fx billede 22; forholdet mellem forskellige meningstyper i en tekst er jo ikke et løg, men kan opfattes i lighed med et løg. iii). Billedet EKSEMPLIFICERER noget der kan have underforstået METONYMISK forbindelse med noget som teksten handler om, fx billede 15; det underforstås: 'sådan kommer man til at se ud når man bruger cremen'.

c) Billet har ingen funktion i forhold til tekstens indhold og er derfor ren dekoration, $\mathrm{fx}$ billederne i den lille bort under billede 9 .

Billedet har også en funktion i forhold til modtagerne : a) Billeder fungerer som INTERESSEVAKKER (for teksten) ved at stå som (en som regel stor) forside på bog, til et kapitel eller til en artikel i et blad eller avis. Forsiden på Alt for damerne.

b) Små billeder kan være anbragt på de sider i teksten hvor det de afbilder, omtales. De ANSKUELIGGøR emner og forhold i teksten som det kan være svært at forklare sprogligt, fx billedet af en finhval i et leksikon.

c) Billederne kan ved deres størrelse helt dominere den komplekse henvendelse som de er del af, selv om de ikke er det vigtigste element i den. Det gælder således de fleste reklamer i glittede blade. Her fungerer de tydeligvis som APрETITVÆKKERE for varer eller motiver (og altså ikke for teksten). i) Hvis billedet er en illustration af det produkt der reklameres for (fx en særlig hovedpude), er billedet opLySENDE. ii) Hvis billedet kun har metonymisk forbindelse med det der reklameres for (damen med den glatte hud der reklamerer for rynkecreme), er billedet BEDRAGERISK, fx billede 15 .

d) Billedet har intet at gøre med tekstens indhold og billedet er derfor rent BLIKFANG som nærmest saboterer tekstens meddelelse, fx den bare dame der reklamerer for bildæk.

Som en demonstration af denne semiotiske teori om forskellen på analoge billeder og digitale tekster, vil jeg kort diskutere de såkaldte håndtegn, som er helleristninger fra ca. 200-100 fvt. Umiddelbart vil man sige at alle eksemplerne er anloge billeder med motivet en hånd med fire pinde lige over fingerspidserne, og man kan næppe afgøre om det er en vestrehånd set bagfra eller en højrehånd set forfra. Men hvorfor er det lavet? Og hvilken virkning har det haft?

Den her opstillede teori vil gøre det nødvendigt at spørge om håndtegnet på billede 26 er et billede som kan kopieres, eller et digitalt tegn som kan gentages? På billede 27 bliver dette spørgsmål endnu mere påtrængende: Er det tre håndtegn på samme kommunikative henvendelse og optræder de da i syntaktisk kombination, eller er billederne bare lavet 
på den samme sten, eventuelt med årtiers mellemrum? Billede 28 viser fire sten som har dannet væggene om et lille (urne?)gravkammer, med billederne indad. De må nødvendigvis være digitaliserede repræsentationer som indgår i kombination med hinanden i en syntaktisk enhed. Er det tilfældet, synes den digitaliserede mening at være nærliggende; efter som de har vendt indad mod et kammer hvor der kun var en urne, kan det være en kommunikativ henvendelse til den afdødes ånd med den mening at den ikke kan slippe ud i menneskenes samfund; de fire pinde kan så være en form for åndefangere. Og er dette rigtigt, er også alle de andre håndtegn digitaliserede tegn som har en bestemt konventionel mening.

26)

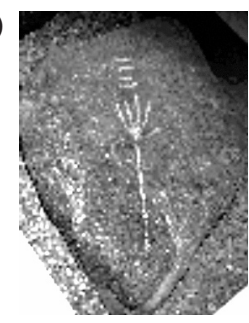

27)

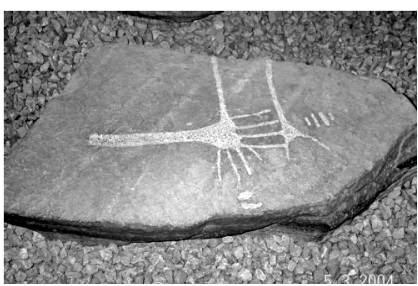

28)

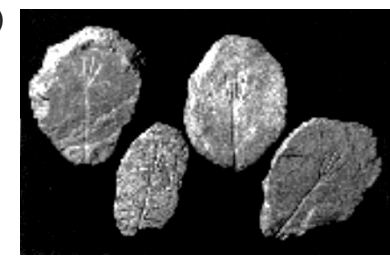

26) Sten fra Følleslev, Norvestsjælland. - 27) Sten fra Lille Havelse, Nordsjælland. - 28) 4 små sten fra Venslev, Sanagergård, Nordsjælland.

\section{LITTERATUR}

Bateson, Gregory (1970, 1971), "Form, Substance and Difference", in: Bateson, Gregory (1973), Steps to an Ecology of Mind. Collected Essays in Anthropology, Psychiatry, Evolution and Epistemology, London: Paladin, pp. 423 - 448.

Chandler, Daniel (2002), Semiotics. The Basics, London: Routledge.

Dretske, Fred (1995), Naturalizing the Mind, Cambridge/Mass.: The MIT Press.

Markvad, Jørgen (2003), Runer og runesten, Gedved: Yduns æbler.

Peirce, Ch. S. (1958), Selected Writings, ed. by Philip P. Wieder, New York: Dover Publications.

Peirce, Ch. S. (1994), Semiotik og pragmatisme, på dansk ved Lars Andersen, udg. af Anne Marie Dinesen og Frederik Stjernfelt, København: Samlerens Bogklub.

Searle, John (1999), Mind, Language and Society. Doing Philosophy in the Real World, London: Weidenfeld \& Nicolson.

Togeby, Ole (2003), Fungerer denne saetning? Funktionel dansk sprogloere, København: Gad.

Togeby, Ole (2005), “Tegn og gerninger”, i: Cramer, Jens, Mette Kunøe, Ole Togeby (red.) (2005), Teorien om alt - og andre artikler om sprog og filosofi, Århus: Wessel og Huitfeldt, pp. 339 - 352.

Watzlawick, Paul, Janet Helmick Beavin, Don D. Jackson (1968), Pragmatics of Human Communication. A Study of Interactional Patterns, Pathologies and Paradoxes, London: Faber and Faber. 


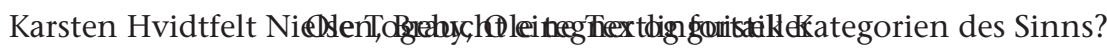

Wilden, Anthony (1972), System and Structure. Essays in Communication and Exchange, London: Tavistock Publications.

Wittgenstein, Ludwig (1958, 1971), Filosofiske undersøgelser, oversat af Jes Barsøe Adolphsen og Lennart Nørreklit, København: Munksgaard. 